\title{
What Determines the Fuel Exports: The Case of Norway
}

\author{
Emmanouil Karakostas
}

ABSTRACT

Energy today is a key factor in economic growth. The reason why energy is today an essential factor for the development of a country is its inelastic demand. Securing energy resources is a key component of many states' trade policy. Within this framework of energy security for many countries, Norway has a remarkable presence. The main reason is the rich mineral wealth that Norway possesses. But that's not the only reason. Many countries, although they have rich mineral resources, are nevertheless "captive" in the rich cradles of mineral resources without wishing to diversify their production ("Dutch Disease" - "The Curse of Resources"). These countries usually have the effect of revaluing their currency and linking it to the dominant world currency. Norway, because of the global energy market, must reform its energy policy in such a way that it can be competitive. This study will attempt to investigate those factors that determine energy exports. Having Norway as a case study, the present research effort will set a framework for the interpretation of energy exports. The methodology applied is multiple Regression Analysis - Ordinary Least Squares (OLS).

Keywords: Fuel Exports, Norway, OLS.

Published Online: January 27, 2022

ISSN: $2736-5506$

DOI : 10.24018/ejenergy.2022.2.1.40

\section{E. Karakostas}

Department of International and European Studies, School of Economics, Business and International Studies, University of Piraeus, Piraeus, Greece.

(e-mail: emkarakwstas@gmail.gr)

*Corresponding Author

\section{INTRODUCTION}

Energy products in today's times are particularly important. The importance of energy is mainly based on the contribution of energy to the economic development of a country. The optimal use of energy can lead directly to the acceleration of economic growth and indirectly through the promotion of exports due to the fact that the optimal use of energy makes the use of the factors of production efficient [1]. Basically, the optimal use of energy resources with energy saving policies leads to GDP growth [2]. According to Georgescu-Roegen, energy is the most important primary component of production in today's era [3]. Norway is a country with a significant presence in the international energy system. Norway's position is very important especially considering the energy dynamic relationship with Europe [4]. According to Hamlehdar and Aslani [5], Norway possesses the second largest reserves of natural gas in Europe, is rich of petroleum and natural gas and is one of the richest nations in the world. They also mention that Norway's exports are for the most part crude oil and natural gas. The question that needs to be answered is this: what are the factors that determine the exports of Norway's fuel products? The answer to this question will be attempted by this research.

The purpose of this study is to explain the causes of the fuel exports of Norway. The remainder of this paper is constructed as follows: the second part mentions the review of the literature. The third part of this research cites the methodology. In the fourth part the results of the regression are cited. The final part concludes. This research it was based on the Linear Regression Analysis - Ordinary Least Squares (OLS). The next section shows a short reference to the literature.

\section{REVIEW OF THE LITERATURE}

Exports of fuel products are a key aspect of international economic relations. The literature of the fuel products is actually divided between three basic categories. The first category is about the importance of energy in a country's economy, the second is about the fuel price formation and the third is about energy consumption. The reason why energy exports have become an important part of the international economy is the importance of energy in a country's economy. References [6]-[12] are the first attempts to investigate the relationship between energy (oil price shocks) and economic activity. References [13]-[22] have shown the relationship of energy products with aspects of the economy. References [23]-[27] have shown that fuel exports do not have a positive effect on economic growth. Much of the existing literature has focused on fuel price formation. Important aspect of this matter is the "Dutch disease". Many surveys analyze the "Dutch disease" [28]-[31]. The "Dutch disease" affects the other productive sectors negatively due to the real appreciation of the national currency. References [32]-[41] explain the "Dutch disease". There are two kinds of researchers that show a unidirectional relationship between energy consumption and economic growth. The first group indicate a unidirectional causality from energy consumption to economic growth [42]-[46] and the second group indicate a unidirectional causality from economic growth to energy consumption [47]-[49]. Moreover, there are researchers that show a bidirectional relationship. They indicate a bidirectional causality specially between economic growth and energy consumption [50]-[55]. References [56]-[58] found no causal connection between economic growth and 
energy consumption. The following segment mentions the methodology and the data of this study.

\section{Methodology And Data}

The present study tries to examine the factors that determine the fuel exports of Norway. The trading partners selected are France, Sweden, United Kingdom, Germany, Netherlands. The countries have been selected because for most of the period under review they are among the five export destinations of Norway. The time period is 1993-2018. The time period and the examining country has chosen firstly and mostly due to the availability of data. Moreover, the time period has chosen due to the fact that covers a sufficient time period analysis.

This study uses multiple-regression model as an estimator of annual time series data. The dependent variable is the percentage of Norway Fuels Export Product Share. The study model expresses the fuels exports of Norway (NO) as a function of firstly, the revealed comparative advantage (RCA) of Norway, the export product share of Norway's intermediate goods, the exchange rate (XR) of Norway, the multifactor productivity (MFP) of Norway, the industrial production (IPI) of Norway's trade partners France (FRAN), Sweden (SE), United Kingdom (UK), Germany (DE), Netherlands (NL) and finally the Gross Domestic Product (GDP) growth of Norway's trade partners. The above are the independent variables. The study uses the traditional Multiple Regression technique, particularly the traditional Ordinary Least Squared (OLS) technique [59]. The database for this study is WITS [60]-[62], OECD [63]-[65] and World Bank [66].

Table I shows the dependent variable and the explanatory variables of the model.

The study sets up the estimated multiple-regression model to test the above stated hypotheses as follows:

FuExpNor $_{i t}=\beta_{o}+\beta_{1}$ FuRCANor $_{t}+\beta_{2}$ IntGExpNor $_{t}+\beta_{3}$ ExcRat Nor $_{t}+\beta_{4}$ MultProNor $+\beta_{5}$ IndProdFr $_{t}+\beta_{6}$ IndProdSw $_{t}+\beta_{7}$ IndP ${\operatorname{rod} U K_{t}+\beta{ }_{8} \text { IndProdGe }}_{t}+\beta{ }_{9}$ IndProdNeth ${ }_{t}+\beta_{10} G D P$

\section{$\mathrm{GrFr}_{t}+\beta_{11} G D P G r w_{t}+\beta_{12} G D P G r U K_{t}+\beta_{13} G D P G r G e r_{t}+\beta_{14} G$ PPGrNeth ${ }_{t}+e_{t}$

Table II displays the description of the variables of the model.

The next section presents the results of linear regression.

\section{RESULTS}

Table III presents the regression results.

The outcomes of linear regression approve the functionality of the above model. The conclusions of this study are demonstrated in the following section.
TABLE II: THE VARIABLES OF THE MODEL

\begin{tabular}{|c|c|}
\hline Variables & $\begin{array}{c}\text { Description } \\
\end{array}$ \\
\hline FuExpNor ${ }_{i t}$ & $\begin{array}{l}\text { Norway Fuels Export Product Share to World } \\
\qquad \text { in } \% \text { 1993-2018 }\end{array}$ \\
\hline$\beta_{0}$ & the constant amount or the intercept \\
\hline$\beta_{1}-\beta_{14}$ & are coefficients of the explanatory variables \\
\hline FuRCANor $_{t}$ & $\begin{array}{l}\text { Norway Fuel Revealed comparative } \\
\text { advantage (RCA) to World 1993-2018 }\end{array}$ \\
\hline IntGExpNor $_{t}$ & $\begin{array}{c}\text { Norway Intermediate goods - Export Product } \\
\text { Share (\%) 1993-2018 }\end{array}$ \\
\hline ExcRatNor $_{\mathrm{t}}$ & $\begin{array}{c}\text { Norway Exchange rate (XR) Total, National } \\
\text { currency units/US dollar 1993-2018 }\end{array}$ \\
\hline MultProNor $_{t}$ & $\begin{array}{c}\text { Norway Multifactor productivity (MFP) } \\
\text { Total, } 2015=100.1993-2018\end{array}$ \\
\hline IndProdFr $r_{t}$ & $\begin{array}{l}\text { Industrial production (IPI) Total } 2015=100 . \\
\qquad 1993-2018 \text { France }\end{array}$ \\
\hline IndProdSw & $\begin{array}{l}\text { Industrial production (IPI) Total } 2015=100 . \\
\qquad 1993-2018 \text { Sweden }\end{array}$ \\
\hline IndProdUK $_{t}$ & $\begin{array}{l}\text { Industrial production (IPI) Total. } 2015=100 . \\
\qquad 1993-2018 \text { United Kingdom }\end{array}$ \\
\hline IndProdGer $_{t}$ & $\begin{array}{l}\text { Industrial production (IPI) Total } 2015=100 . \\
\qquad 1993-2018 \text { Germany }\end{array}$ \\
\hline IndProdNeth $_{t}$ & $\begin{array}{l}\text { Industrial production (IPI) Total } 2015=100 . \\
\qquad 1993-2018 \text { Netherlands }\end{array}$ \\
\hline $\mathrm{GDPGrFr}_{\mathrm{t}}$ & GDP growth (annual \%) 1993-2018 France \\
\hline $\mathrm{GDPGrSw}_{\mathrm{t}}$ & GDP growth (annual \%) 1993-2018 Sweden \\
\hline GDPGrUK $_{t}$ & $\begin{array}{c}\text { GDP growth (annual \%) 1993-2018 United } \\
\text { Kingdom }\end{array}$ \\
\hline GDPGrGer $_{\mathrm{t}}$ & GDP growth (annual \%) 1993-2018 Germany \\
\hline $\mathrm{GDPGrNeth}_{\mathrm{t}}$ & $\begin{array}{l}\text { GDP growth (annual \%) 1993-2018 } \\
\text { Netherlands }\end{array}$ \\
\hline $\mathrm{e}$ & the error term \\
\hline $\mathrm{t}$ & the year from the period $1993-2018$ \\
\hline $\mathrm{i}$ & the country \\
\hline
\end{tabular}

TABLE II: REGRESSION RESULTS

Dependent Variable: FuExpNor

\begin{tabular}{cc} 
FuRCANor & $-3.558 *(-6.245,-0.871)$ \\
IntGExpNor & $-2.504 * * *(-3.444,-1.565)$ \\
ExcRatNor & $-0.880(-2.726,0.967)$ \\
MultProNor & $-0.171(-0.729,0.387)$ \\
IndProdFr & $0.177(-0.434,0.789)$ \\
IndProdSw & $0.408(-0.114,0.931)$ \\
IndProdUK & $0.041(-0.514,0.596)$ \\
IndProdGer & $-0.270 *(-0.532,-0.008)$ \\
IndProdNeth & $-0.587 *(-1.159,-0.016)$ \\
GDPGrFr & $1.195(-1.004,3.394)$ \\
GDPGrSw & $-0.324(-1.420,0.772)$ \\
GDPGrUK & $-0.191(-1.295,0.912)$ \\
GDPGrGer & $0.645(-0.620,1.911)$ \\
GDPGrNeth & $-0.888(-2.011,0.234)$ \\
e & $0.162(-0.673,0.996)$ \\
\hline Constant & $151.761 * *(88.914,214.609)$ \\
Observations & 26 \\
R & 0.982 \\
Adjusted R & 0.956 \\
idual Std. Error & $1.562(\mathrm{df}=10)$ \\
F Statistic & $36.941 * *(\mathrm{df}=15 ; 10)$ \\
\hline Note: & $<<0.05 ; * * \mathrm{p}<0.01$ \\
\hline
\end{tabular}


TABLE I: THE DEPENDENT VARIABLE AND THE EXPLANATORY VARIABLES OF THE MODEL

\begin{tabular}{|c|c|c|c|c|c|c|c|c|c|c|c|c|c|c|c|}
\hline Year & $\begin{array}{c}\text { Fuels Export } \\
\text { Product Share to } \\
\text { World in \% } \\
\text { (NO) } \\
\end{array}$ & $\begin{array}{l}\text { Fuel RCA to } \\
\text { World } \\
\text { (NO) }\end{array}$ & $\begin{array}{c}\text { Intermediate } \\
\text { goods - Export } \\
\text { Product Share (\%) } \\
\text { (NO) } \\
\end{array}$ & $\begin{array}{c}\text { XR Total, } \\
\text { National currency } \\
\text { units/US dollar, } \\
\text { (NO) } \\
\end{array}$ & $\begin{array}{l}\text { MFP Total, } \\
2015=100 \\
\text { (NO) }\end{array}$ & $\begin{array}{l}\text { IPI Total, } \\
2015=100 \\
\text { (FRA) }\end{array}$ & $\begin{array}{l}\text { IPI Total, } \\
2015=100 \\
\text { (SE) }\end{array}$ & $\begin{array}{l}\text { IPI Total, } \\
2015=100, \\
\text { (UK) }\end{array}$ & $\begin{array}{l}\text { IPI Total, } \\
2015=100 \\
\text { (DE) }\end{array}$ & $\begin{array}{l}\text { IPI Total, } \\
2015=100 \\
\text { (NL) }\end{array}$ & $\begin{array}{l}\text { GDP growth } \\
\text { annual } \% \\
\text { (FRAN) }\end{array}$ & $\begin{array}{c}\text { GDP } \\
\text { growth } \\
\text { annual \% } \\
(\mathrm{SE}) \\
\end{array}$ & $\begin{array}{c}\text { GDP } \\
\text { growth } \\
\text { annual } \\
\% \text { (UK) } \\
\end{array}$ & $\begin{array}{c}\text { GDP } \\
\text { growth } \\
\text { annual } \\
\% \text { (DE) } \\
\end{array}$ & $\begin{array}{c}\text { GDP } \\
\text { growth } \\
\text { annual } \\
\%(\mathrm{NL}) \\
\end{array}$ \\
\hline 1993 & 51.26 & 5.39 & 16.2 & 7.094 & 86.1 & 86.8 & 69.2 & 80.2 & 67.1 & 78.9 & $\begin{array}{c}-0.62 \\
\end{array}$ & -2.06 & 2.48 & -0.97 & 1.25 \\
\hline 1994 & 49.61 & 6.2 & 17.19 & 7.058 & 89.3 & 90.0 & 77.0 & 84.5 & 69.2 & 82.7 & 2.35 & 3.92 & 3.84 & 2.39 & 2.96 \\
\hline 1995 & 47.28 & 6.22 & 18.54 & 6.335 & 92.1 & 92.7 & 84.5 & 86.0 & 69.8 & 85.1 & 2.1 & 3.93 & 2.53 & 1.54 & 3.11 \\
\hline 1996 & 54.65 & 5.86 & 15.28 & 6.450 & 94.9 & 93.5 & 85.2 & 87.2 & 69.4 & 87.2 & 1.41 & 1.57 & 2.49 & 0.8 & 3.49 \\
\hline 1997 & 53.79 & 6.28 & 15.43 & 7.073 & 97.0 & 97.5 & 89.2 & 89.4 & 71.8 & 86.7 & 2.33 & 3.07 & 4.97 & 1.79 & 4.32 \\
\hline 1998 & 43.27 & 6.76 & 18.55 & 7.545 & 96.4 & 101.6 & 93.3 & 92.3 & 75.0 & 88.4 & 3.58 & 4.31 & 3.7 & 2.01 & 4.66 \\
\hline 1999 & 49.94 & 6.56 & 15.8 & 7.799 & 96.5 & 104.3 & 95.9 & 96.5 & 76.2 & 91.0 & 3.42 & 4.24 & 3.29 & 1.88 & 5.03 \\
\hline 2000 & 63.89 & 5.64 & 12.55 & 8.802 & 98.9 & 108.6 & 101.5 & 99.0 & 80.4 & 95.9 & 3.92 & 4.76 & 3.5 & 2.91 & 4.19 \\
\hline 2001 & 61.75 & 5.82 & 12.31 & 8.992 & 101.0 & 109.9 & 100.5 & 101.3 & 80.5 & 95.9 & 1.98 & 1.44 & 2.73 & 1.68 & 2.32 \\
\hline 2002 & 60.63 & 6.04 & 13.16 & 7.984 & 102.6 & 108.6 & 100.5 & 103.0 & 79.5 & 97.0 & 1.13 & 2.19 & 2.17 & -0.19 & 0.21 \\
\hline 2003 & 61.17 & 5.04 & 13.41 & 7.080 & 104.8 & 107.7 & 102.0 & 105.8 & 79.7 & 95.8 & 0.82 & 2.3 & 3.32 & -0.7 & 0.15 \\
\hline 2004 & 63.62 & 4.93 & 13.54 & 6.741 & 106.6 & 110.1 & 107.7 & 104.5 & 83.1 & 99.9 & 2.82 & 4.33 & 2.28 & 1.17 & 1.98 \\
\hline 2005 & 67.68 & 4.32 & 12.24 & 6.442 & 107.4 & 110.0 & 110.4 & 103.7 & 85.9 & 100.2 & 1.66 & 2.85 & 2.95 & 0.73 & 2.05 \\
\hline 2006 & 67.8 & 3.92 & 12.47 & 6.413 & 106.5 & 110.8 & 113.8 & 107.1 & 90.9 & 102.3 & 2.44 & 4.66 & 2.69 & 3.81 & 3.46 \\
\hline 2007 & 64.29 & 3.85 & 14.48 & 5.862 & 104.8 & 112.0 & 117.7 & 106.2 & 96.9 & 106.5 & 2.42 & 3.43 & 2.36 & 2.97 & 3.77 \\
\hline 2008 & 68.87 & 3.49 & 11.26 & 5.640 & 101.2 & 109.0 & 114.6 & 104.4 & 97.7 & 107.3 & 0.25 & -0.45 & -0.27 & 0.95 & 2.17 \\
\hline 2009 & 62.98 & 3.74 & 12.06 & 6.288 & 99.7 & 95.4 & 94.5 & 98.4 & 80.8 & 99.4 & -2.87 & -4.33 & -4.11 & -5.69 & -3.66 \\
\hline 2010 & 63.69 & 3.52 & 12.62 & 6.044 & 99.3 & 99.9 & 103.4 & 97.5 & 90.4 & 106.9 & 1.94 & 5.95 & 2.07 & 4.17 & 1.34 \\
\hline 2011 & 68.02 & 3.35 & 11.49 & 5.605 & 98.1 & 102.4 & 105.9 & 91.7 & 98.1 & 106.4 & 2.19 & 3.19 & 1.27 & 3.92 & 1.55 \\
\hline 2012 & 69.81 & 3.2 & 9.69 & 5.817 & 98.8 & 99.8 & 103.5 & 91.9 & 97.1 & 105.9 & 0.31 & -0.58 & 1.43 & 0.41 & -1.03 \\
\hline 2013 & 67.62 & 3.21 & 9.55 & 5.875 & 98.7 & 99.5 & 98.6 & 94.1 & 97.0 & 106.5 & 0.57 & 1.18 & 2.18 & 0.43 & -0.13 \\
\hline 2014 & 64.87 & 3.36 & 10.29 & 6.302 & 99.1 & 98.4 & 97.0 & 95.7 & 99.0 & 103.6 & 0.95 & 2.65 & 2.86 & 2.2 & 1.42 \\
\hline 2015 & 57.68 & 4.15 & 12.3 & 8.064 & 100.0 & 100.0 & 100.0 & 100.0 & 100.0 & 100.0 & 1.11 & 4.48 & 2.36 & 1.49 & 1.95 \\
\hline 2016 & 52.97 & 4.57 & 13.43 & 8.400 & 100.1 & 100.5 & 102.1 & 100.2 & 101.5 & 101.4 & 1.09 & 2.07 & 1.72 & 2.22 & 2.19 \\
\hline 2017 & 57.18 & 4.42 & 13.08 & 8.272 & 101.5 & 102.5 & 106.5 & 100.3 & 104.5 & 102.5 & 2.29 & 2.56 & 1.74 & 2.68 & 2.91 \\
\hline 2018 & 62.12 & 3.93 & 12.02 & 8.133 & 100.8 & 103.2 & 109.0 & 103.8 & 105.7 & 103.1 & 1.86 & 1.95 & 1.25 & 1.08 & 2.36 \\
\hline
\end{tabular}




\section{CONCLUSION}

From the examination of the data, it is observed that the model composed in the present research has a high explanatory ability. The model presented has showed the functionality and importance of the chosen independent variables. Adjusted $\mathrm{R}^{2}$ is high, with value of 0.956 . This means that the model built in this research describes the connection of independent variables to the dependent one. Essentially, the bigger the Adjusted $\mathrm{R}^{2}$ the better the model fits to the data. The variables FuRCANor, IntGExpNor, ExcRatNor, MultProNort, IndProdGert, IndProdNeth, GDPGrSw $_{t}$, GDPGrUK, , GDPGrNeth ${ }_{t}$, have a negative effect on the fuel exports whereas the other variables have a positive effect. Norway is a country whose presence in the energy sector is particularly important. The factors chosen in this model explain the exports of energy products. Further research is needed to establish a satisfactory analytical framework for fuel exports.

\section{FUNDING}

This work was self-funded.

\section{REFERENCES}

[1] Thapa-Parajuli R, Aryal S, M. Alharthi M, Paudel RC. Energy consumption, export performance and economic growth in a landlocked developing country: The case of Nepal. AIMS Energy. 2021; 9(3):516-533.

[2] Asghar Z. Energy-GDP Relationship: A Causal Analysis for the Five Countries of South Asia. Applied Econometrics and International Development. 2008; 8-1:167-180.

[3] Georgescu-Roegen N. The Entropy Law and the Economic Process. Harvard University Press, 1971.

[4] Austvik OG. Norway: Small State in the Great European Energy Game. International Political Economy Series. 2019.

[5] Hamlehdar M, Aslani, A. Analysis of Energy System in Norway with Focus on Energy Consumption Prediction. Management of Sustainable Development Sibiu. 2017; 9(1): 5-14.

[6] Rasche R, Tatom J. The effects of the new energy regime on economic capacity, production, and prices. Review, Federal Reserve Bank of St. Louis, 1977; May: 2-12.

[7] Rasche R, Tatom J. Energy price shocks, aggregate supply and monetary policy: the theory and the international evidence. CarnegieRochester Conference Series on Public Policy. 1981; 14(1): 9-93.

[8] Darby M. The Price of oil and World inflation and Recession. American Economic Review. 1982; 72(4): 738-751.

[9] Hamilton J. Oil and the Macroeconomy Since World War II. Journal of Political Economy. 1983; 91: 228-248.

[10] Burbidge J, Harrison A. Testing for the Effects of Oil-Price Rises using Vector Autoregressions. International Economic Review. 1984; 25(2): 459-84.

[11] Santini D. The Energy-Squeeze Model: Energy Price Dynamics in U.S. Business Cycles. International Journal of Energy Systems. 1985; 5: 1825.

[12] Gisser M, Goodwin T. Crude Oil and the Macroeconomy: Tests of Some Popular Notions. Journal of Money, Credit, and Banking. 1986; 18: 95-103.

[13] Hooker MA. What Happened to the Oil Price-Macroeconomy Relationship? Journal of Monetary Economics. 1996; 38: 195-213.

[14] Rotemberg J, Woodford M. Imperfect Competition and the Effects of Energy Price Increases on Economic Activity. Journal of Money, Credit and Banking. 1996; 28(4): 550-577.

[15] Bernanke B, Gertler M, Watson M. Systematic Monetary Policy and the Effects of Oil Price Shocks. Brookings Papers on Economic Activity. 1997; 1: 91-157.

[16] Barsky R, Kilian L. Oil and the Macroeconomy Since the 1970s. Journal of Economic Perspectives. 2004; 18(4): 115-134.

[17] Lee K, Ni S, Ratti RA. Oil shocks and the Macroeconomy: The role of Price Variability. Energy Journal. 1995; 16(4): 39-56.
[18] Papapetrou E. Oil prices shocks, stock market, economic activity and employment in Greece. Energy Economics. 2001; 23: 511-532.

[19] Miguel C, Manzano B, Martin-Moreno J. Oil price shocks and aggregate fluctuations. The Energy Journal. 2003; 24(2): 47-61.

[20] Limin D, He Y, Chu W. The relationship between oil price shocks and China's macro-economy: An Empirical analysis. Energy Policy. 2010; 38(8): 4142-4151.

[21] Cunado J, Perez de Gracia F. Do oil price shocks matter? Evidence from some European countries. Energy Economics. 2003; 25: 137-154.

[22] Mehrara M, Oskoui K. The source of macroeconomic fluctuations in oil exporting countries: A comparative study. Economic Modelling. 2007; 24(3): 365-379.

[23] Herzer D, Nowak-Lehmann FD, Siliverstovs B. Export-led growth in Chile: Assessing the role of export composition in productivity growth. Developing Economies. 2006; 44(3): 306-328.

[24] Hosseini SMP,Tang CF. The effects of oil and non-oil exports on economic growth: A case study of the Iranian economy. Economic Research-Ekonomska Istraživanja. 2014; 27(1): 427-441.

[25] Kalaitzi AS, Cleeve E. Export-led growth in the UAE: Multivariate causality between primary exports, manufactured exports and economic growth. Eurasian Business Review. 2017; 8(3): 341-365.

[26] Myrdal G. Economic theory and under-developed regions. London: Gerald Duckworth and Co. 1957.

[27] Kalaitzi AS, Chamberlain TW. Fuel-mining exports and growth in a developing state: The case of the UAE. International Journal of Energy Economics and Policy. 2020; 10(4): 300-308.

[28] Corden WM, Neary JP. Booming sector and de-industrialisation in a small open economy. The Economic Journal. 1982; 92(368):825-848.

[29] Sachs JD, Warner AM. Natural resource abundance and economic growth. National Bureau of Economic Research, Working Paper. 1995; 5398.

[30] Papyrakis E, Gerlagh R. Resource abundance and economic growth in the United States. European Economic Review. 2007; 51(4): 10111039.

[31] Iimi A. Escaping from the resource curse: evidence from Botswana and the rest of the world. IMF Staff Papers. 2007; 54: 663-699.

[32] Bellemare MF, Barrett CB, Just DR. The welfare impacts of commodity price volatility: evidence from rural Ethiopia. American Journal of Agricultural Economics. 2013; 95(4): 877-899.

[33] Dwyer A, Gardner G, Williams T. Global commodity markets-price volatility and financialization. Reserve Bank of Australia. 2011; 49-57.

[34] Tujula M, Wolswijk G. What determines fiscal balances? An empirical investigation in determinants of changes in OECD budget balances. Working Paper Series No. 422 / December 2004, European Central Bank. 2004.

[35] Dehn J. Commodity price uncertainty in developing countries, World Bank, [Internet]. 2000 Available from: https://doi.org/10.1596/18139450-2426

[36] De Ferranti D, Perry GE, Lederman, D, Maloney WE. From natural resources to the knowledge economy: trade and job quality, World Bank. [Internet]. 2002 Available from: https://doi.org/10.1596/0-82135009 .

[37] Masten SE, Crocker KJ. Efficient adaptation in long-term contracts: take-or-pay provisions for natural gas. The American Economic Review. 1985; 75(5): 1083-1093.

[38] Gylfason T. Natural resources, education, and economic development. European Economic Review. 2001; 45(4-6):847-859.

[39] Lam R, Wantchekon L. Political Dutch disease, manuscript. Department of Politics. New York University. [Internet]. 2003 Available from: http://neumann.hec.ca/neudc2004/fp/wantchekon_leonard_avril_16.p df.

[40] Hodler R. The curse of natural resources in fractionalized countries. European Economic Review. 2006; 50(6): 1367-1386.

[41] Deacon RT, Rode A. Rent seeking and the resource curse. 2015; X-X.

[42] Stern D. A multivariate cointegration analysis of the role of energy in the US macroeconomy. Energy Economics. 2000; 22(2): 267-283.

[43] Oh W, Lee K. Causal relationship between energy consumption and GDP revisited: the case of Korea 1970-1999. Energy Economics. 2004; 26(1): 51-59.

[44] Soytas U, Sari R. Energy consumption and GDP: causality relationship in G-7 countries and emerging markets. Energy Economics. 2003; 25(1): 33-37.

[45] Sari R, Ewing BT, Soytas U. The relationship between disaggregate energy consumption and industrial production in the United States: An ARDL approach. Energy Economics. 2008; 30(5): 2302-2313.

[46] Narayan PK, Smyth R. Energy consumption and real GDP in G7 countries: New evidence from panel cointegration with structural breaks. Energy Economics. 2008; 30(5): 2331-2341. 
[47] Mehrara M. Energy consumption and economic growth: The case of oil exporting countries, Energy Policy. 2007; 35(5): 2939-2945.

[48] Halicioglu F. An econometric study of CO2 emissions, energy consumption, income and foreign trade in Turkey. Energy Policy. 2007; 37(3): 1156-1164.

[49] Narayan PK, Smyth R. Electricity consumption, employment and real income in Australia evidence from multivariate Granger causality tests. Energy Policy. 2005; 33(9): 1109-1116.

[50] Lee CC. The causality relationship between energy consumption and GDP in G-11 countries revisited. Energy Policy. 2006; 34(9): 10861093.

[51] Lee CC, Chang CP. Energy consumption and GDP revisited: A panel analysis of developed and developing countries. Energy Economics. 2007; 29(6): 1206-1223.

[52] Masih AMM, Masih R. On the temporal causal relationship between energy consumption, real income, and prices: Some new evidence from Asian-energy dependent NICs Based on a multivariate cointegration/vector error-correction approach. Journal of Policy Modeling. 1997; 19(4): 417-440.

[53] Asafu-Adjaye J. The relationship between energy consumption, energy prices and economic growth: time series evidence from Asian developing countries. Energy Economics. 2000; 22(6): 615-625.

[54] Ghali KH, El-Sakka M. Energy use and output growth in Canada: a multivariate cointegration analysis. Energy Economics. 2004; 26(2): 225-238.

[55] Erol U, Yu ESH. On the causal relationship between energy and income for industrialized countries. Journal of Energy Development. 1987; 13: 113-122.

[56] Payne JE. On the dynamics of energy consumption and output in the US. Applied Energy. 2009; 86(4): 575-577.

[57] Akinlo AE. Energy consumption and economic growth: Evidence from 11 Sub-Sahara African countries. Energy Economics. 2008; 30(5): 2391-2400.

[58] Altinay G, Karagol E. Electricity consumption and economic growth: Evidence from Turkey. Energy Economics. 2005; 27(6): 849-856.

[59] Hutcheson GD. Ordinary Least-Squares Regression. The SAGE Dictionary of Quantitative Management Research. 2011; 224-228.

[60] WITS. Norway Fuel Export Product Share to World. [Internet]. 2021 Available

from https://wits.worldbank.org/CountryProfile/en/Country/NOR/StartYear /1993/EndYear/2019/TradeFlow/Export/Indicator/XPRT-PRDCTSHR/Partner/WLD/Product/Fuels.

[61] WITS. Norway Fuel Revealed comparative advantage to World. [Internet]. $2021 \quad$ Available from: https://wits.worldbank.org/CountryProfile/en/Country/NOR/StartYear /1993/EndYear/2019/TradeFlow/Export/Indicator/RCA/Partner/WLD Product/Fuels.

[62] WITS. Norway Intermediate goods Export Product Share to World [Internet]. $2021 \quad$ Available from: https://wits.worldbank.org/CountryProfile/en/Country/NOR/StartYear /1993/EndYear/2019/TradeFlow/Export/Indicator/XPRT-PRDCTSHR/Partner/WLD/Product/UNCTAD-SoP2.

[63] OECD. Exchange rates Total, National currency units/US dollar, 1993 - 2018. [Internet]. 2021 Available from: https://data.oecd.org/conversion/exchange-rates.htm.

[64] OECD. Multifactor productivity Total, Annual growth rate (\%), 1993 - 2018. [Internet]. 2021 Available from: https://data.oecd.org/lprdty/multifactor-productivity.htm.

[65] OECD. Industrial production Total, 2015=100, $1993-2018$ [Internet]. 2021 Available from: https://data.oecd.org/industry/industrial-production.htm.

[66] World Bank. GDP growth (annual \%) - France, Sweden, United Kingdom, Germany, Netherlands. [Internet]. 2021 Available from: https://data.worldbank.org/indicator/NY.GDP.MKTP.KD.ZG?locatio $\mathrm{ns}=\mathrm{FR}-\mathrm{SE}-\mathrm{GB}-\mathrm{DE}-\mathrm{NL}$. 